\title{
Acoustic Prosodic Parameters in Japanese and Slovene: ACCENT AND INTONATION
}

\author{
Nina GOLOB \\ University of Ljubljana \\ nina_glb@yahoo.com
}

\begin{abstract}
The study investigates realizations of the three acoustic parameters, duration, fundamental frequency and intensity, in relation to accent and intonation in Japanese and Slovene. Ten native speakers of each language pronounced nonsense words of different accentual patterns placed within the declarative-interrogative intonational context. Results of the acoustic analysis reveal clear differences in behavior of the three parameters under various conditions, and suggest the following phonological differences between the two languages: 1. Prosodic features realizing accent and intonation differ, 2. Interaction between accent and intonation differs, and 3. Prosodic features function uniformly within different units of successive segments, the so-called prosodic units. However, looking into the overall characteristics of the acoustic signal, certain similarities are also observed. The study anticipates that the above phonological differences, especially those realized as phonetic similarities represent a great difficulty in acquisition of L2 prosody, and specific examples of a possible L1 interference are provided.
\end{abstract}

\section{Keywords}

Japanese, Slovene, accent, intonation, prosodic features

\section{Izvleček}

Raziskava obravnava tri osnovne akustične parametre (trajanje, osnovno frekvenco in intenziteto) in njihovo razločevalno funkcijo pri besednem naglasu oz. intonaciji v japonščini in slovenščini. Po deset govorcev za vsak jezik je bralo nesmiselne besede, ki so bile vstavljene v povedne in vprašalne stavke. Rezultati akustične analize so pokazali očitne razlike v obnašanju akustičnih parametrov pod različnimi pogoji, iz katerih avtor sklepa o naslednjih fonoloških razlikah med japonščino in slovenščino: 1. prozodične lastnosti, ki oblikujejo besedni naglas in intonacijo, se razlikujejo, 2. interakcija med besednim naglasom in intonacijo se razlikuje, 3. enotno delovanje prozodičnih lastnosti se zgodi znotraj različnih fonotaktičnih sklopov, t.i. prozodičnih enot. Hkrati opazovanje splošnih karakteristik akustičnega signala nakazuje tudi na določene podobnosti med jezikoma. Raziskava podaja splošno spoznanje, da omenjene fonološke razlike v prozodiji japonščine in slovenščine, še posebej tiste, ki se v govoru realizirajo kot fonetične podobnosti, predstavljajo veliko oviro pri usvajanju japonšščine oz. slovenščine kot tujega jezika. Dodani so tudi konkretni primeri predvidenega vpliva maternega jezika na učenje tujega jezika.

\section{Ključne besede}

japonščina, slovenščina, besedni naglas, intonacija, prozodične lastnosti 


\section{Introduction}

Except for a few articles and presentations written by the author (Golob, 2004a; Golob, 2004b), nothing within the broad area of phonetics and phonology has yet been done on comparison between Japanese and Slovene. A pilot-study ${ }^{1}$ at the University of Ljubljana $^{2}$ showed that Slovene students of Japanese have great difficulties with Japanese pronunciation, especially with the part of it concerning accent and intonation. Mispronunciations revealed certain patterns that are thought to be the result of the first language interference, and thus an insight into differences and similarities between Japanese and Slovene prosody should provide valuable information for further research on foreign language acquisition as well as on language universals and typology ${ }^{3}$.

The present study is concerned with the acoustic realization of accent in declarative and interrogative intonational contexts in Japanese and Slovene. Attention is directed to prosodic features ${ }^{4}$ of length, pitch and loudness and their acoustic counterparts within the $\mathrm{CV}$ and/or $\mathrm{CVN}^{5}$ phonotactic sequences, and their correlation with accent and intonation.

The following three questions are discussed:

i) Which prosodic features correlate with accent and intonation?

ii) How do accent and intonation interact in terms of their relevant prosodic features?

iii) What kind of segmental formation, called prosodic unit, do prosodic features indicate?

To answer i) and ii) phonotactically unmarked (canonical) consonant+vowel sequence (CV) is employed, and words consisting of either two or three of such sequences placed into all possible accentual patterns within declarative and interrogative intonation are introduced. Comparisons of pairs of words that only differ in one factor (the so-called minimal pairs) are expected to reveal the correlative prosodic features $^{6}$ and the way they correlate in Japanese and Slovene, respectfully.

\footnotetext{
${ }^{1}$ Unpublished.

${ }^{2}$ Department of Asian and African Studies, Japanology.

${ }^{3}$ Gass and Selinker (1983) write that contrastive analyses are not only useful for pedagogical purposes (e.g. making lists of hypothetical problems in learning a foreign language) but also for purely linguistic purposes (e.g. discussing language contact situations, language transfer with bilinguals etc.).

${ }^{4}$ Phonetic features.

${ }^{5} \mathrm{~N}$ is a an alveolar nasal.

${ }^{6}$ For example, phonological accent, be it stress, tone or pitch accent, is acoustically either partially or fully realized by fundamental frequency Fo, the latter also being the main intonational acoustic parameter. For discussion on only those prosodic features correlating with intonation, comparison between words that keep all factors (segmental surrounding, accent pattern, etc.) but intonational context the same will be conducted.
} 
After the first two questions having been answered, CVN sequence is considered to discuss question iii). CVN sequence, where $\mathrm{N}$ represents an alveolar nasal, is - apart from the $\mathrm{CVQ}^{7}$ sequence, in which $\mathrm{Q}$ only realizes duration and is for that reason left out of the discussion - the only possible C1VC2 sequence in Japanese, and is at the same time one of the well-formed structures in Slovene. Supposing a CV sequence as a basic prosodic unit, $\mathrm{CVN}$ sequence is once compared to one $\mathrm{CV}$ sequence $(\mathrm{CVN}=\mathrm{CV})$ and once to two $\mathrm{CV}$ sequences $(\mathrm{CV}+\mathrm{N}=\mathrm{CV}+\mathrm{CV})$. Comparisons are expected to confirm or disprove the individual character of $\mathrm{N}$ in the two languages, respectfully.

Numerous studies on Japanese prosody offer a great amount of phonological discussions as well as empirical studies. Regardless of the theoretical models authors follow, it is well established that Standard Japanese ${ }^{8}$ is a pitch accent, mora-timed language, where a characteristic pitch pattern, a high-low tonal sequence, marks the word accent, and is governed by mora timing ${ }^{9}$. Mora is traditionaly defined in terms of absolute duration and any $\mathrm{CV}, \mathrm{V}, \mathrm{N}$ or $\mathrm{Q}$ is in its length proportional to one mora (Hattori, 1960; Kindaichi, 1967; etc.). The definition of isochrony was reconsidered by Lehiste (1977), who draw a distinction between perceptual (psychological) and phonetic isochrony. It is proven that mora in Japanese does not /always/ capture phonetic reality (Sugitoo, 1982; Beckman, 1982; etc.). Naming mora as an accent bearing unit, Sugitoo (1982) defined the so-called "late fall" [ososagari] phenomenon, an acoustic phenomenon in which the peak of fundamental frequency is not seen on the phonologically accented mora but is instead shifted to the following mora ${ }^{10}$. She also showed that intensity curve suggests no systematic response to accented mora and suggested that fundamental frequency is the basic cue making up accent (Sugitoo, 1982).

Compared to Japanese, acoustics of Slovene prosody is in many ways still an unchallenged topic. Numerous dialects with two different accent types - some dialects have stress accent and some pitch accent ${ }^{11}$ - blending in a small geographical area makes it difficult to define Standard Slovene ${ }^{12}$. Lehiste (1961) analyzed the Maribor

\footnotetext{
${ }^{7} \mathrm{Q}$ is a glottal plosive.

${ }^{8}$ Standard Japanese is nowadays equated with the Tokyo dialect. The difference between Standard Japanese and Common Japanese has disappeared.

${ }^{9}$ The concept of mora is found in the work of Trubetzkoy (1969/1939), who drew distinctions between "syllable-counting" and "mora-counting" languages, and placed Japanese into the latter group.

${ }^{10}$ The phenomenon was first observed by Neustupny (1966). It tends to occur in initally accented words whose second mora has a non-high vowel and does not influence the perception. She argues that rather than peak of the fundamental frequency the downward movement induces a percept of accent (Sugitoo, 1982).

${ }^{11}$ According to the review of the previous studies, what is called pitch accent in Slovene seems to be phonetically (acoustically) different from what is called pitch accent in Japanese. However, there is yet no contrastive study that could support this thought.

${ }^{12}$ According to Toporišič (1976/2000, p. 63) "official Slovene can have either stress or pitch accent. Since pitch accent is used in the dialect of the capital Ljubljana, pitch accent is thought as preferential" (my translation).
} 
speech, which belongs to one of the stress accent dialects (Rigler, 1968), and her findings suggest that "three prosodic systems are simultaneously present in Standard Educated Slovene: stress, pitch and quantity" out of which "stress system appears to be primary"13. Toporišič in his works discusses both accent types, however, bases mainly on perceptional impressions. His data concerning stress accent (Toporišič, 2000/1976, p. 63) agree with those of Lehiste (1961) saying that "loudness together with high pitch marks the accent place, of which only loudness is distinctive"14, and he continues the tradition of recognizing two specific tones in pitch accent dialects (Toporišič, 1978): the rising tone (acute) and the falling tone (circumfleks). The tones, which are characteristic for accented syllables only, were phonologically redefined in relation to the following syllables as low and high, respectively, but "their phonetic interpretation remains unsatisfactory" (Toporišič, 1978, p. 225). A detailed work on acoustics of Slovene pitch accent as spoken in Ljubljana was written by Srebot-Rejec (1988), who expreses doubt on the accurate usage of the formal pitch accent in Standard Slovene nowadays. The thought was further debated by Tivadar\&Jurgec (2003) and Jurgec (2005) concluding that stress-accented speech is nowadays regarded as more neutral, and as such preffered in public use.

\section{Experimental investigation}

\subsection{Method}

\subsubsection{Material}

Material used in the present study was chosen following the study on reiterant speech by Larkey (1983). Twelve nonsense words (Table 1) with successively more scope for voicing and different accent patterns ${ }^{15}$ were embedded in carrier phrases such as A: What is this? ...word...? B: Yes. ...word..., designed to elicit declarative and interrogative intonational characteristics of the words used.

\footnotetext{
${ }^{13}$ What Lehiste in her work calls "stress" is named intensity (loudness) in this study (see Lehiste 1970 for explanation on relation between stress and intensity/loudness).

${ }^{14}$ My translation.

${ }^{15}$ Accent pattern was marked according to standard accent markings in both languages. In Japanese, accent mark was placed on perceptually the last high mora, and in Slovene, on the stressed syllable. Due to the confusion of whether or not pitch accent is still in use in Standard Slovene, and also to the fact that Slovene children only learn markings for stress accent at school (Herrity, 2000), only stress accent is accounted for for Slovene in this study.
} 
Table 1: A list of nonsense words used in a research

\begin{tabular}{|c|c|c|c|c|c|c|c|c|c|}
\hline \multicolumn{5}{|c|}{ Japanese } & \multicolumn{5}{|c|}{ Slovene } \\
\hline $\begin{array}{l}\text { phonemic } \\
\text { sequence }\end{array}$ & $\begin{array}{l}\text { accent } \\
\text { pattern }\end{array}$ & 1 mora & 2 mora & 3 mora & 1 syll. & 2 syll. & 3 syll. & $\begin{array}{l}\text { stress } \\
\text { place }\end{array}$ & $\begin{array}{l}\text { phonemic } \\
\text { sequence }\end{array}$ \\
\hline \multirow{3}{*}{$\mathrm{CV}$} & head-high & な & なな & まなま & na & nana & manama & 1. syll. & \multirow{3}{*}{$\mathrm{CV}$} \\
\hline & mid-high & 1 & 1 & なまま & 1 & mana & namama & 2. syll. & \\
\hline & no-high & ま & まな & ななま & 1 & 1 & nanama & 3. syll. & \\
\hline \multirow{3}{*}{$\mathrm{CVN}$} & head-high & 1 & なん & まんた & nan & manta & I & 1. syll. & \multirow{3}{*}{$\mathrm{CVN}$} \\
\hline & mid-high & 1 & 1 & なまん & 1 & naman & 1 & 2. syll. & \\
\hline & no-high & I & まん & なんた & 1 & nanta & 1 & 2. syll. & \\
\hline
\end{tabular}

The words fulfil phonotactic conditions of each language and either consist of CV sequences alone or also include a CVN sequence. Pronounced in two different languages, the same word keeps its accent place but differs in accent type. Such a pair of pronunciations of the same word is called a "cross-linguistic minimal pair" in this study.

\subsubsection{Subjects}

Twenty female native speakers, ten for each langauge, were the subjects in the study. Japanese subjects were native speakers of the Tokyo dialect, while Slovene speakers were from 3 different areas, Ljubljana, Trbovlje and Celje ${ }^{16}$. All were in their twenties and had no hearing or speaking problems.

\subsubsection{Recording procedures and acoustic analyses}

Most of the recordings were conducted in a soundproof studio, some of them in a silent room (four Slovene speakers). They were digitized at a sampling rate of 44.1 $\mathrm{kHz}$ and processed by Praat 4.2.

The three acoustic parameters, duration, Fo and intensity were measured in the following way (Figure 1). First, borders between phonemes were defined and duration was measured for each CV sequence. Then, Fo and intensity values were extracted at four places of each vowel: its beginning and end, and the two mid-points.

\footnotetext{
${ }^{16}$ Ljubljana speech is traditionally thought of as pitch accent dialect but in recent years the change into stress accent area is very rapid. Trbovlje and Celje speech belong to stress accent dialects.
} 


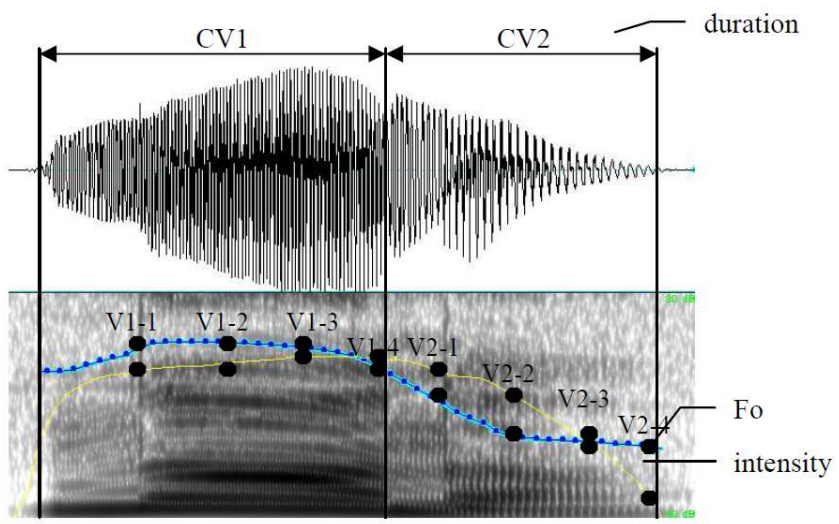

Figure1: Examples of prosodic feature extraction.

Adjusting analyses to the purpose of the study, $\mathrm{N}$ of the CVN sequence was analyzed in two different ways. Firstly, $\mathrm{N}$ was treated in the same way as a $\mathrm{CV}$ sequence, and its duration, Fo and intensity were measured according to the above explanation for CV sequence. Secondly, $\mathrm{N}$ was treated as an inherent part of the whole CVN structure, and thus the duration of the whole CVN was measured. Fo and intensity were measured on the $\mathrm{CN}$ sequence in the same way as the vowel of a $\mathrm{CV}$ sequence.

\subsubsection{Handling the data}

Acoustic parameters and their systematic behavior were interpreted in connection to the phonological accent and intonation. The three questions, 1. Which prosodic features correlate with accent and intonation?, 2. How do accent and intonation interact in terms of their relevant prosodic features?, and 3. What kind of segmental formation, or prosodic unit, do prosodic features indicate?, were discussed as follows. First, by comparing the parameters of phonologically accented $\mathrm{CV}$ with the surrounding unaccented $\mathrm{CV}$ sequences of the same word ${ }^{17}$, acoustic parameters responding to accent place were defined, and furthermore, by comparing the parameters in different intonational contexts of the same word, acoustic parameters responding to intonational contexts were defined. Second, by eliminating the relevant parameters, their systematic behavior was analyzed, and the interaction of parameters responding to accent place and those responding to intonational context was proposed. Third, by comparing acoustic characteristics of the $\mathrm{CVN}$ sequence to the $\mathrm{CV}$ sequence, segment $\mathrm{N}$ was defined either as an independent prosodic unit or as a constituent of a larger CVN unit according to its prosodic function.

\footnotetext{
${ }^{17}$ A word has at most one (primary) accent place both in Japanese and Slovene.
} 


\subsection{Results}

\subsubsection{CV structure}

Lack of space only allows a presentation of the words containing three successive $\mathrm{CV}$ sequences. Tendencies described below are equally applicable to the words of two consecutive CV sequences.

\section{Duration}

Figure 2, 3 show average durations for each word and their respective CV sequences for the pronunciations by 10 Japanese (left) and 10 Slovene speakers (right).

There is a general tendency in both languages shortly described as: the closer to the end of the word the greater the duration of a CV sequence. It is observed in all cases regardless of accentual and intonational patterns. The observed lengthening phenomenon would need further statistical analyses but can generally be described as one of the language-independent prosodic features (Vaissiere, 1983). Having no linguistic function it will be left out of further discussion.
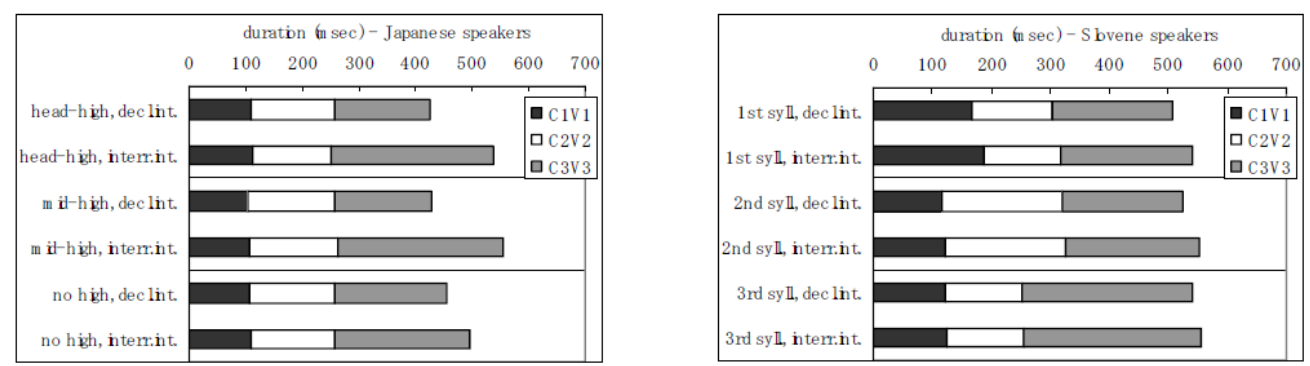

Figure 2, 3: Average durations for Japanese (left) and Slovene speech (right)

The Japanese data suggest no response of duration to accent place, showing no differences in durations of $\mathrm{CV}$ sequences among the words under different accentual conditions neither in declarative nor in interrogative intonation. It is however observed that duration is responsive to intonational contexts because the duration of the whole word in interrogative intonation is greater than that in declarative intonation. Furthermore, except for the final $\mathrm{CV}$ sequence all $\mathrm{CV}$ sequences are found to be of roughly the same duration. The final $\mathrm{CV}$ sequence in interrogative intonation carries greater duration compared to the $\mathrm{CV}$ sequence of the same position in declarative intonation.

Results for Slovene show different tendencies. As for accent, duration shows responses to different patterns by realizing higher values for the accented $\mathrm{CV}$ sequences compared to the surrounding unaccented CV sequences. On the other hand, the data reveals no responses to intonational contexts, showing negligible durational 
differences of the whole words as well as the respective CV sequences within different intonational contexts.

Fo

Figures $4 \mathrm{a}-4 \mathrm{c}$ (from top to bottom on the left) and 5a-5c (from top to bottom on the right) show the average Fo curves in bold line and individual Fo curves for 10 Japanese and 10 Slovene speakers, respectfully.
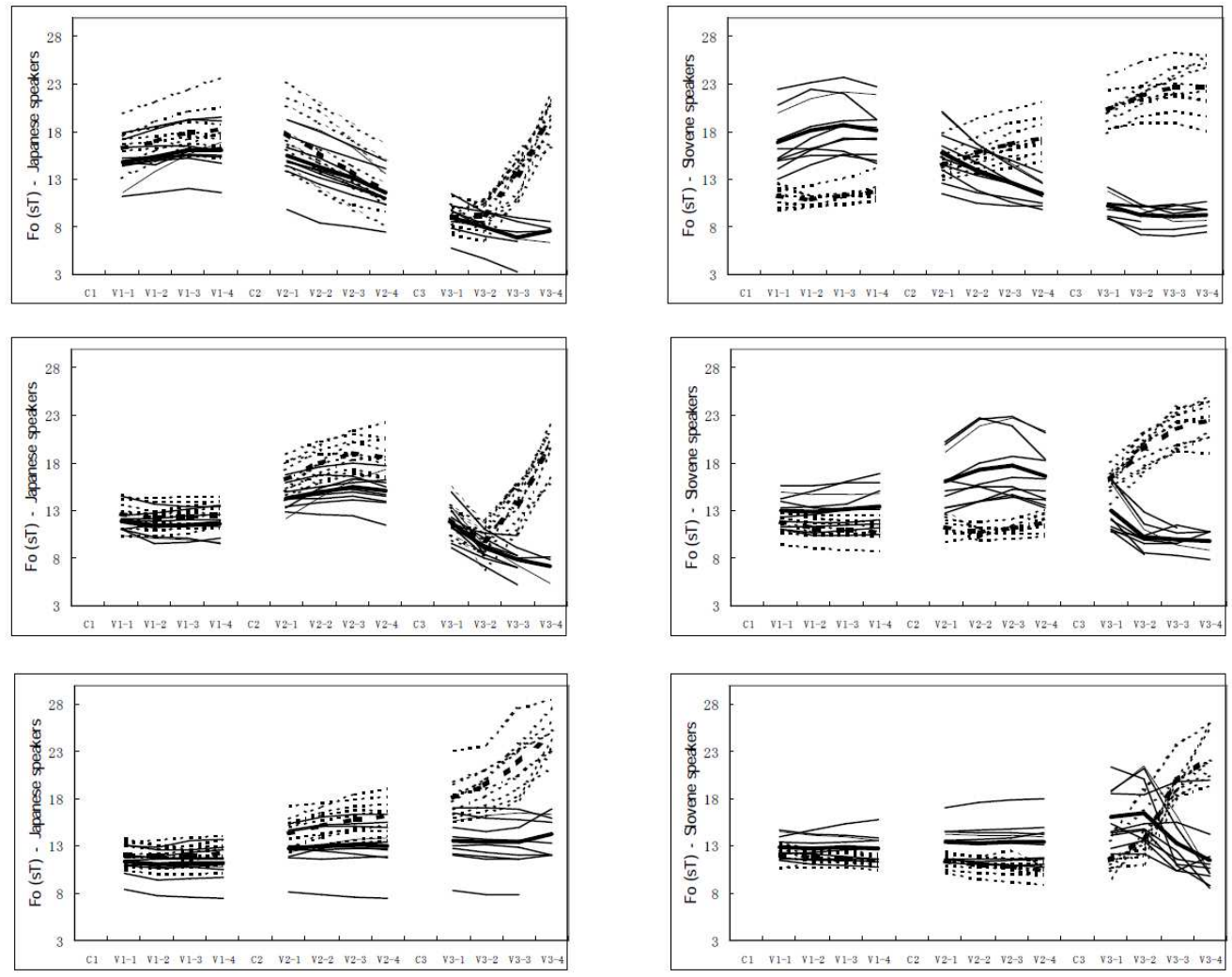

Figures 4a, 4b, 4c and 5a, 5b, 5c: Fo curve ${ }^{18}$ for Japanese (left) and Slovene speech (right) in words with different accentual patterns.

In both languages Fo curve shows specific responses to accentual patterns as well as intonational context.

${ }^{18}$ Full lines illustrate Fo curves in declarative intonation and dotted line in interrogative intonation. Figures a above represent words accented on the first CV sequence, figures $b$ in the middle words accented on the middle CV sequence and figures c below represent the Japanese unaccented word (left) and Slovene word accented on the last $\mathrm{CV}$ sequence (right). 
In Japanese, a rising Fo curve on the accented CV sequence followed by a relatively steep fall on the following $\mathrm{CV}$ sequence, low Fo values on the $\mathrm{CV}$ sequence preceding the accented CV sequence, and finally, a rising-flat Fo curve through the whole unaccented word, are the uniform characteristics for declarative intonational contexts. Fo curves in the interrogative context of the same word show similar movements until the last CV sequence in unaccented word (Figure 4c) and until the middle of the last CV sequence in accented words (Figure 4a, 4b). After that a steep rise is observed in all cases.

Compared to Japanese, Fo curve in Slovene shows different behavior. Words in declarative intonation realize Fo peaks roughly in the middle of the accented CV sequence, and the peak is preceded by a steady rise of Fo in the preceding $\mathrm{CV}$ sequences. Fo curve flattens by the end of the word. There is a reversed interdependence observed between the Fo curves in declarative and interrogative intonation, that is, in the place where Fo curve reaches its highest value in declarative intonation it realizes its lowest value in interrogative intonation. Fo curves keep the reversed interdependence after the extreme Fo values, showing a gradual fall in declarative intonation, and a gradual rise in interrogative intonation.

\section{Intensity}

Figures $6 \mathrm{a}-6 \mathrm{c}$ (from top to bottom on the left) and 7a-7c (from top to bottom on the right) show the average intensity curves in bold line and individual intensity curves for 10 Japanese and 10 Slovene speakers, respectfully.
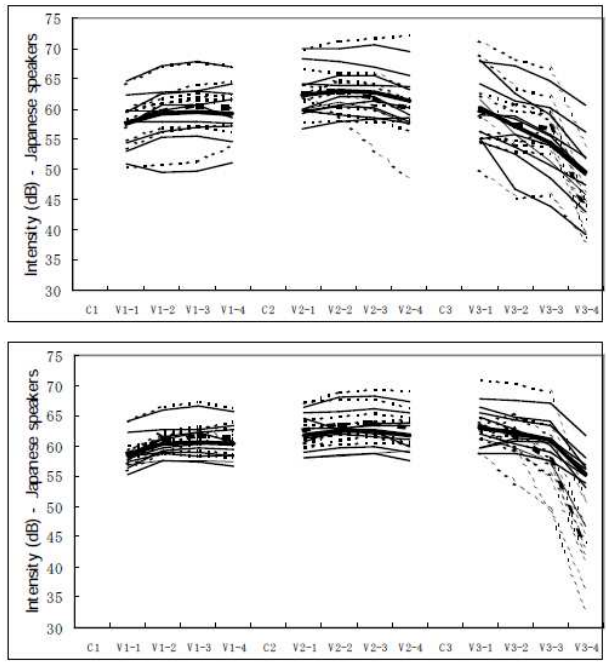
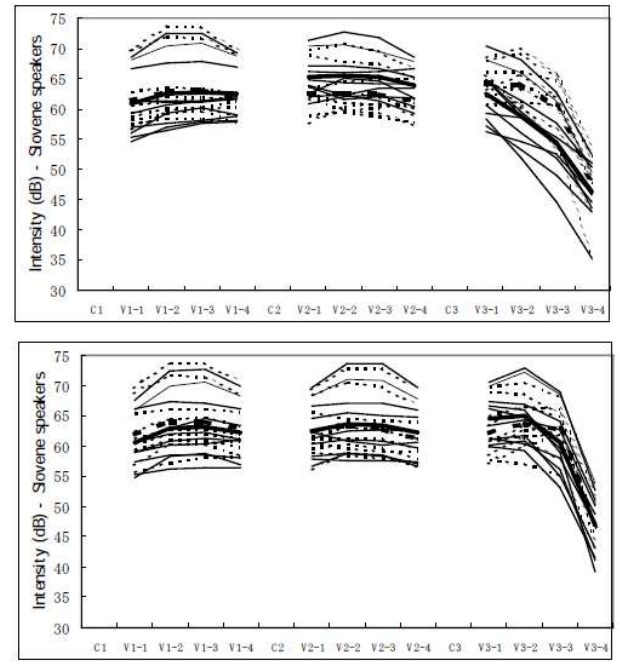

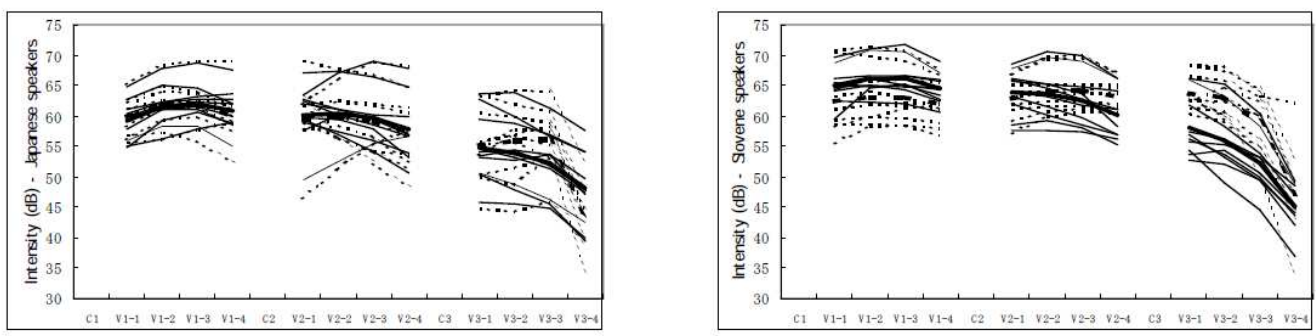

Figures 6a, 6b, 6c and 7a, 7b, 7c: Intensity $\operatorname{curves}^{19}$ for Japanese (left) and Slovene speech (right) in words with different accentual patterns.

The data show a main difference between Japanese and Slovene in that intensity curves reveal no response either to accentual or to intonational patterns in Japanese. The dispersion of intensity curves, also reported by Sugitoo (1982) is particularly large at the end of the words.

In Slovene, intensity curve shows particular responses to both accentual and intonational patterns, however, the two types of tendencies do not disclose any interaction. In words with declarative intonation intensity curve is similar to Fo curve: intensity peak is realized roughly in the middle of the accented CV sequence, and is preceded by a steady rise and followed by a steady fall in most cases. On the other hand, intensity curve in words with interrogative intonation shows the same movements regardless of accent patterns. Instead, a gradual rise is observed from the beginning until the middle of the last $\mathrm{CV}$ sequence where it changes to a fall.

\section{Discussion}

Japanese and Slovene words consisting of CV sequences were analyzed and the data revealed that values of certain acoustic parameters change according to the changes of accentual patterns or intonational contexts. Such acoustic evidence suggests the existence of more abstract relations, correlations of prosodic features with accent and intonation illustrated in Table 2.

Table 2: Results on feature responses

\begin{tabular}{||l|c|c|c|c||}
\hline & \multicolumn{2}{|c|}{ Japanese } & \multicolumn{2}{c||}{ Slovene } \\
\hline & accent & intonation & accent & intonation \\
\hline \hline length (duration) & - & + & + & - \\
\hline pitch (Fo) & + & + & + & + \\
\hline loudness (intensity) & - & - & + & + \\
\hline
\end{tabular}

\footnotetext{
${ }^{19}$ Full lines illustrate intensity curves in declarative intonation and dotted lines in interrogative intonation. Figures a above represent words accented on the first $\mathrm{CV}$ sequence, figures $\mathrm{b}$ in the middle words accented on the middle CV sequence and figures c below represent the Japanese unaccented word (left) and the Slovene word accented on the last $\mathrm{CV}$ sequence (right).
} 
In the data for Japanese, only pitch correlates with accent, and pitch and length correlate with intonation. As for Slovene, all three features correlate with accent, while pitch and loudness correlate with intonation.

From the observations on how the relevant prosodic features behave under different accentual and intonational conditions the following phonetic conclusions were made.

a. Japanese:

- rising pitch on the accented $\mathrm{CV}$ sequence compared to the falling pitch afterwards

- greater length of the final $\mathrm{CV}$ sequence in interrogative intonation compared to the declarative one.

b. Slovene:

- greater length of the accented CV sequence compared to the surrounding $\mathrm{CV}$ sequences, and pitch and intensity extreme values on the accented CV sequence,

- pitch and intensity peak on the accented CV sequence in declarative intonation. In interrogative intonation, a rising tendency of pitch after its lowest value on the accented $\mathrm{CV}$ sequence, and the intensity peak on last $\mathrm{CV}$ sequence with no relation to accentual pattern.

\subsubsection{CVN structure}

With the CVN structure only representative data is shown in details and prosodic features that were proven not correlate with accent and intonation (see 2.2.1.) are thought as irrelevant in the case of CVN sequences as well.

In this section two different sound segments, a vowel and a nasal, will be compared acoustically, which consequently brings the need to consider their intrinsic acoustic qualities. According to Lehiste (1970), first, intrinsic duration of a nasal is shorter to the one of a vowel, and a CV sequence is intrinsically longer than $\mathrm{N}$ alone. Second, compared to vowels intrinsic Fo is lower for nasals. And third, intrinsic intensity of vowels is greater than that of nasals.

\section{Duration}

Figure 8 and 9 show the data for duration in Japanese (left) and Slovene (right).

It is interesting to note that in declarative intonation the word duration as well as the duration of the segment $\mathrm{N}$ alone is roughly the same in Japanese and Slovene, being remarkably shorter for the nasal compared to the CV sequence. This supports the previous findings that there is no phonetic isochrony of moras in Japanese (Beckman, 1982; Sugitoo, 1982; etc.). 
The Japanese data reveal durational responses to intonational contexts in the same way as described for $\mathrm{CV}$ sequences in 2.2.1. The final sequence - be it $\mathrm{CV}$ or $\mathrm{N}$ but not $\mathrm{CV}$ and $\mathrm{N}-$ is significantly longer in interrogative than in declarative intonation.

In Slovene, there is no immediate difference seen in the duration of $\mathrm{N}$ between the stressed and unstressed CVN sequence even though there is a difference in the duration of the $\mathrm{CV}$ sequence alone. To examine the existence of durational differences of $\mathrm{N}$ further statistical analysis would be needed.
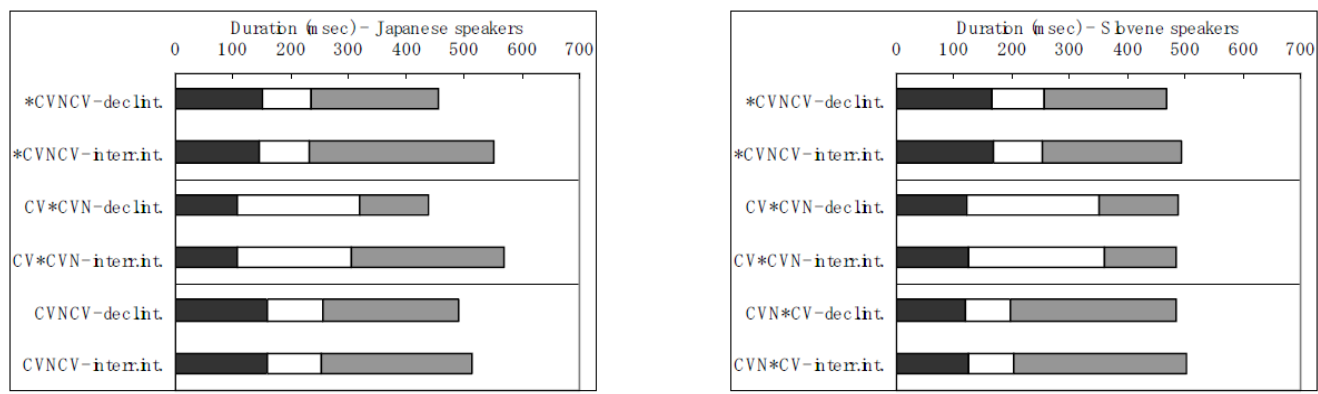

Figure 8, 9: Average durations for Japanese (left) and Slovene speech (right). Asterisk marks accent place.

Fo

Japanese data (Figure 10a, 10b) for fundamental frequency show that the rising Fo curve for $\mathrm{N}$ can only be realized when the unaccented $\mathrm{CVN}$ sequence takes the initial place in a word, the tendency that proves to be (partially) independent from accent patterns. What suggests Fo curve for $\mathrm{N}$ to behave independently from the proceeding $\mathrm{CV}$ sequence and similarly to Fo curve of any other CV sequence is its final position in a word where $\mathrm{CV}$ sequence proceeding $\mathrm{N}$ is accented. In such case Fo curve over the $\mathrm{CVN}$ sequence takes a typically fall-rise curve in the final position of an interrogative intonation, which is comparable to two CV sequences (Figure 10a). Fo curve of the whole CVN sequence has no similar counterpart in a single CV sequence (Figure 10b). 

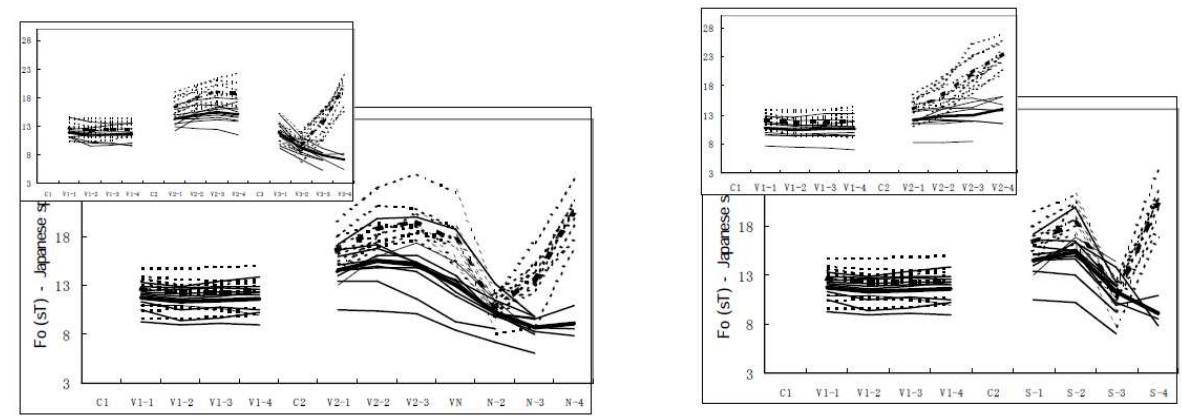

Figure 10a, 10b: Fo curve of the Japanese word “naman”「なま

where $\mathrm{CVN}$ is once taken as 2 units $(\mathrm{CV}+\mathrm{N}$, left) and once as one unit (CVN, right), and compared to three $\mathrm{CV}$ sequence and two CV sequence words, respectively.

An example of a Fo curve shape from Slovene is presented in Figure 11a and 11b. Characteristic response of Fo curve to accentual patterns, as was described in 2.2.1., is marked with its extreme values in the middle of the accented vowel. In case of a CVN structure, of which CV is accented, Fo peak is realized in the middle of the whole CVN structure (11b) and not in the middle of CV structure alone (11a). This suggests that Fo curve realized by $\mathrm{N}$ completes the Fo curve of the preceding $\mathrm{CV}$ into a shape that is comparable to a Fo curve of any other accented $\mathrm{CV}$ sequences.
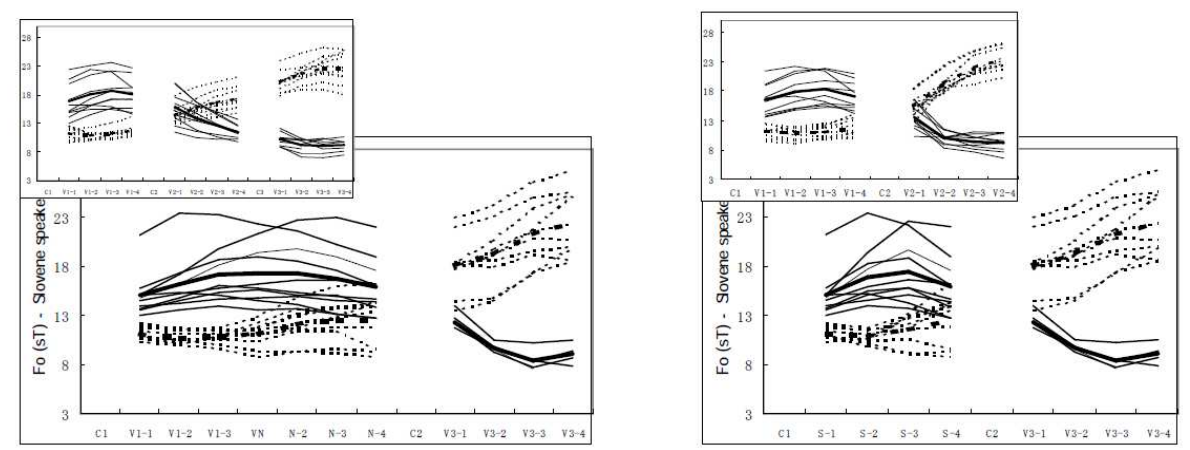

Figure 11a, 11b: Fo curve of the Slovene word "mánta" where CVN is once taken as 2 units $(\mathrm{CV}+\mathrm{N}$, left $)$ and once as one unit (CVN, right), and compared to three $\mathrm{CV}$ sequence and two $\mathrm{CV}$ sequence words, respectively

\section{Intensity}

Intensity is characterized as a responsive acoustic parameter in Slovene only, and thus the discussion on Japanese is omitted.

Figures 12a, 12b, 13a and 13b illustrate intensity curves of two Slovene words building a minimal pair by differing in accentual pattern. Comparing them, as well as 
observing their intensity curves within CVN structure does not give any straight suggestions whether $\mathrm{N}$ realizes intensity independently or within a CVN sequence, and further statistical analysis would be needed to examine it.
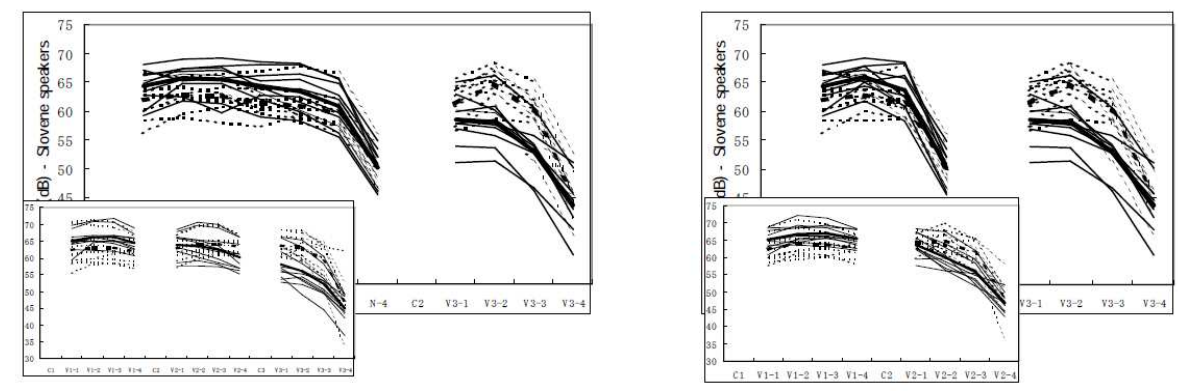

Figure 12a, 12b: Intensity curve of the Slovene word "mánta" where CVN is once taken as 2 units $(\mathrm{CV}+\mathrm{N}$, left $)$ and once as one unit $(\mathrm{CVN}$, right), and compared to three $\mathrm{CV}$ sequence and two $\mathrm{CV}$ sequence words, respectively
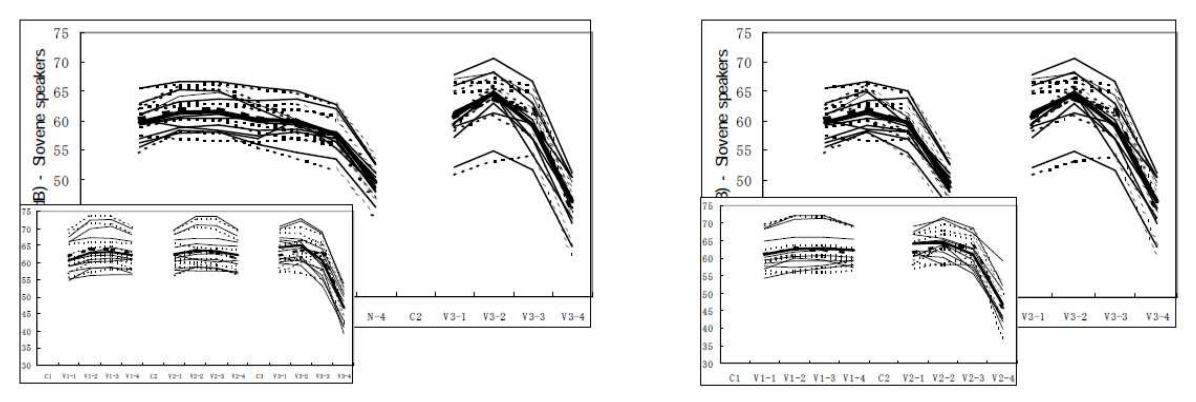

Figure 13a, 13b: Intensity curve of the Slovene word "mánta" where CVN is once taken as 2 units $(\mathrm{CV}+\mathrm{N}$, left) and once as one unit $(\mathrm{CVN}$, right), and compared to three $\mathrm{CV}$ sequence and two CV sequence words, respectively.

\section{Discussion}

In previous sections the three acoustic parameters were analyzed for CVN sequence. The analysis was conducted in two ways, once as a $\mathrm{CV}+\mathrm{N}$ sequence and the other time as a CVN sequence. Tendencies of the behavior of the parameters were compared to those of two successive CV sequences and one CV sequence, respectfully, and a prosodic unit for each language was suggested as illustrated in Table 3. 
Table 3: Prosodic unit in Japanese and Slovene according to the behavior of prosodic features

\begin{tabular}{|l|c|c|c|c|c|c|c|c||}
\hline & \multicolumn{4}{|c|}{ Japanese } & \multicolumn{5}{c|}{ Slovene } \\
\cline { 2 - 10 } & \multicolumn{2}{|c|}{ accent } & \multicolumn{2}{|c|}{ intonation } & \multicolumn{2}{c|}{ accent } & \multicolumn{2}{c|}{ intonation } \\
& N & CVN & N & CVN & N & CVN & N & CVN \\
\hline length (duration) & $/$ & $/$ & + & - & - & $\triangle$ & $/$ & $/$ \\
\hline pitch (Fo) & + & - & + & - & - & + & - & + \\
\hline loudness (intensity) & $/$ & $/$ & $/$ & $/$ & + & + & + & + \\
\hline Overall & + & - & + & - & - & + & - & + \\
\hline
\end{tabular}

In Japanese, pitch movements of the segment $\mathrm{N}$ alone show responses to accent and intonation similar to any $\mathrm{CV}$ sequence in the same position, which is not the case for the CVN structure as a whole. Furthermore, duration of the segment $\mathrm{N}$ alone when in a word-final position is greater in interrogative than in declarative intonation. The two observations confirm the prosodically independent character of the segment $\mathrm{N}$ in Japanese.

On the other hand, there was no similarity found for the tendencies of length and pitch between the segment $\mathrm{N}$ alone and a CV sequence in Slovene. The data suggest that the whole CVN sequence realizes a feature response that is comparable to any other CV sequence in the same position. However, further statistical analysis is needed to prove the statement. Finally, loudness, which responds to both accent and intonation in Slovene, offers no straight data of whether the segment $\mathrm{N}$ is an independent variable or not, and observations keep both possibilities open for discussion.

In overall, it can be concluded that $\mathrm{N}$ in Japanese behaves as any other $\mathrm{CV}$ sequence and thus forms a prosodic unit on its own. This is not the case for Slovene, where $\mathrm{N}$ constitutes a unit with the preceding $\mathrm{CV}$ sequence, and is as such comparable to any other $\mathrm{CV}$ sequence under the same conditions. CVN sequence is then considered as one prosodic unit.

\section{Overall discussion}

The main goal of the study was to answer the following three questions: 1 . Which prosodic features correlate with accent and intonation, 2. What is the interaction between accent and intonation, and finally, 3. What is the prosodic unit in each language. The latter was discussed on the CVN sequence, where a clear distinction in the behavior of the features was observed between the two languages. While in Japanese, features for the segment $\mathrm{N}$ alone behave similarly to features for any other $\mathrm{CV}$ sequence, this is not the case in Slovene, where a whole CVN sequence is comparable to a $\mathrm{CV}$ sequence. These conclusions agree with the previous studies on what is called moraic character of the nasal $\mathrm{N}$ in Japanese and a closed syllable in 
Slovene (see 1. Introduction), however, are reached from a different perspective, namely from the acoustic analyses of the behaviour of the three prosodic parameters in different accentual and intonational patterns, rather than their absolute values.

Presuming the difference on the prosodic unit, the following discussion will operate with models for relevant prosodic features. The above data (Table 2) showed that pitch correlates with accent and intonation in both languages, which can on the surface be taken as a phonological similarity between the two languages. However, a detailed overview of the way pitch correlates with either accent or intonation under different conditions, also taking other relevant features into account, suggests a straightforward difference in the interaction between the features correlating with accent and those correlating with intonation. In other words, specific pitch patterns suggest a phonological difference in the interaction of accentual and intonational domain between Japanese and Slovene, in short, between accent and intonation.

Figure 14 illustrates modeled relevant features, pitch and length, for Japanese. A full line represents declarative intonation and a dotted line interrogative intonation. Models of all the words used in the study are presented, therefore the lines are divided on a time domain into one, two or three successive groups (from top to bottom), each group representing one prosodic unit. There is a dot placed above the prosodic unit marking the accent place.

Models of pitch and length together reveal that the pitch rise characterizing interrogative intonation is executed after all the information for the accentual domain have been realized, suggesting a declarative intonational to be phonetically described as "neutral" or phonologically as a "zero intonation". In other words, phonetically, there is a linear interaction between accentual and intonational domain, in which the latter follows former on time domain. More abstractly, supposing that both accentual and intonational domain exist throughout the whole time domain, accentual domain overlays the intonational one.

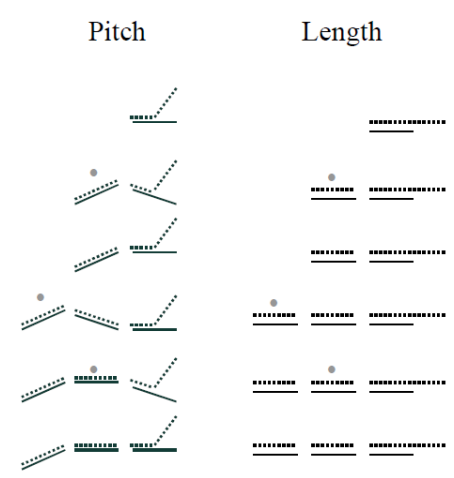

Figure 14: Modeled patterns of pitch and length in Japanese 
The above data for Slovene revealed all three prosodic features to be relevant, and their models are shown in Figure 15. In two different intonational contexts, unchanged timing domain suggests overlapping interaction between accentual and intonational domain that is revealed mainly through pitch patterns. These show a reversed interdependence best seen on the accented prosodic units. On the other hand, loudness in interrogative intonation takes the shape that indicates no interaction either with the loudness pattern in declarative intonation or with the accented prosodic unit. The fact might prove to be significant for the interpretation of the relation among the three features, and is written here only to propose a topic for a new investigation.

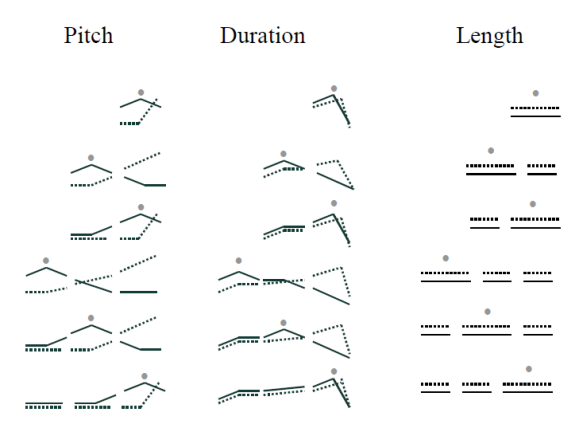

Figure 15: Modeled patterns of relevant features for Slovene

\subsection{Predictions: L1 interference in acquisition of Japanese as L2}

Three types of phonological differences were discussed in the previous section. To name them as discussed throughout the study, the first difference is in the prosodic features that correlate with either accent or intonation, or both. The second difference is in the way the relevant features behave, which suggests a different interaction between accent and intonation. Lastly, the third difference is in the so-called prosodic unit, or the function of the segment $\mathrm{N}$ in Japanese and Slovene, respectively.

However, as mentioned in the oveall discussion (chap. 3, para. 2), the surface or phonetic form shows certain similarities between the two languages that will be presented below. Comparison of pitch patterns for declarative intonational context is illustrated in Figure 16a (left) and that for interrogative intonational context in Figure $16 \mathrm{~b}$ (right). In both figures Japanese pitch models are placed on the left side and Slovene pitch models on the right side. Such a left-right pair of pitch models corresponds to a cross-linguistic minimal pair. The arrows indicate similarities of basic pitch movements, a series of rises and falls, between the two languages. 

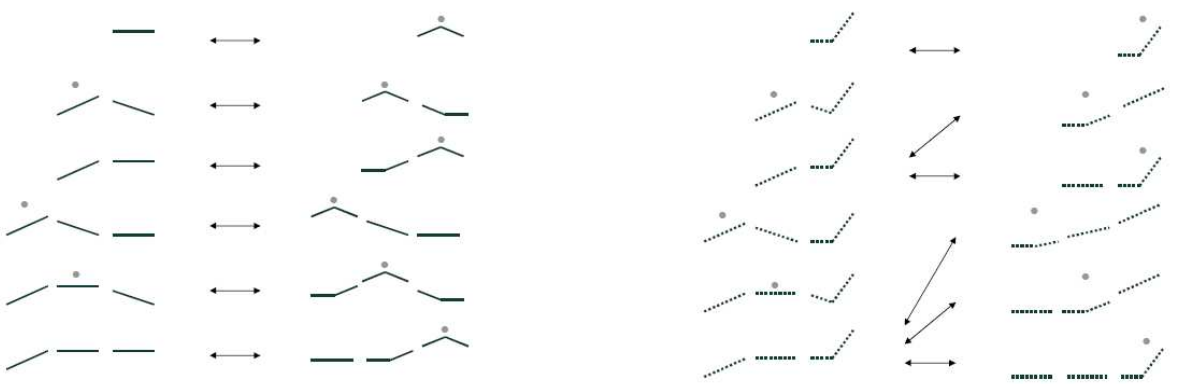

Figure 16a, 16b: Surface similarities of pitch patterns for declarative (left) and interrogative intonational context (right)

In declarative intonational context, similarities are observed within the crosslinguistic minimal pairs, while this is not the case for all such minimal pairs in interrogative intonational context. Comparison suggests that Slovene pitch models in all accentual patterns reflect Japanese pitch models of the unaccented words.

The above findings have practical implications for the prediction of first language interference for Slovene students of Japanese. First language interference is a process of language transfer, in which "the learning of task A will affect the subsequent learning of task B" (Jakobovits, 1970, p.188) in a negative way. The process incorporates the view that patterns of a native language, including both forms (phonetics) and functions of elements (phonology), are superimposed on the patterns learned in a second language.

It is predicted that the aspects of those phonological differences that also reflect in phonetic differences will largely effect communication and will result in misinterpretations of the meaning on the side of the listener. On the other hand will phonological differences that partially reflect in phonetic similarities effect the communication to the level, where the meaning is conveyed successfully but the speaker's pronunciation is described as having a foreign accent. According to Kellerman's framework of language transparency (Kellerman, 1977), language transfer is more likely to occur in the case where two languages are close in rules and forms. The above combination of phonological differences and phonetic similarities is predicted to cause language interference, greater than that originating from phonological and phonetic differences. 


\section{References}

Beckman, M. E. (1982). Segment duration and the 'mora' in Japanese. Phonetica, 39, 113-135.

Golob, N. (2004a). Perception of Japanese pitch accent by Slovene native speakers: the role of music ability. Japanese Studies: Research and Education, 8. Tokyo: Tokyo University of Foreign Studies. [in Japanese]

Golob, N. (2004b). Phonological approach to acoustic analysis of Japanese and Slovene prosody: accent and intonation I. Paper presented at the conference of The Phonetic Society of Japan (Nihon'onseigakkai) in Tokyo, September 2004. [in Japanese]

Hattori, S. (1960). Gengogaku no Hoohoo. Tokyo: Iwanami Shoten. [in Japanese]

Herrity, P. (2000). Slovene: A Comprehensive Grammar. New York: Routledge.

Jakobovits, L. (1970). Foreign Language Learning. Rowley: Mass. Newbury House.

Jurgec, P. (2005). Recent findings on tone in Slovenian. Paper presented at the conference Between Stress and Tone, Leiden, the Netherlands, June 2005.

Kellerman, E. (1977). Towards a characterisation of the strategy of transfer in second language acquisition. I.S.B., 2.1, 58-146.

Kindaichi, H. (1967). Nihongo On'in no Kenkyuu. Tokyo: Tookyoodoo Shuppan. [in Japanese]

Larkey, L.S. (1983). Reiterant speech: an acoustic and perceptual validation. Journal of the Acoustical Society of America, 73 (4), 1337-1345.

Lehiste, I. (1961). The phonemes of Slovene. International Journal of Slavic Linguistics and Poetics, IV, 49-66.

Lehiste, I. (1970). Suprasegmentals. Cambridge: MIT Press.

Lehiste, I. (1977). Isochrony reconsidered. Journal of Phonetics, 5, 253-264.

Neustupny, J. (1966). Is the Japanese accent a pitch accent? Onseigakkai Kaihou, 121. Reprinted in Tokugawa, M. (ed.). (1980). Akusento (pp. 230-239). Tokyo: Yuuseedoo.

Rigler, J. (1968). Problematika naglaševanja v slovenskem knjižnem jeziku. Jezik in slovstvo, $X I I / 6,192-199$. [in Slovene]

Srebot-Rejec, T. (1988). Word Accent and Vowel Duration in standard Slovene: An Acoustic and Linguistic Investigation. Muenchen: Otto Sagner.

Sugitoo, M. (1982). Nihongo Akusento no Kenkyuu. Tokyo: Sanseidoo. [in Japanese]

Tivadar, H. \& Jurgec, P. (2003). Podoba govorjenega knjižnega jezika v Slovenskem pravopisu 2001. Slavistična revija L1/2. [in Slovene]

Toporišič, J. (1978). Glasovna in naglasna podoba slovenskega jezika. Maribor: Obzorja. [in Slovene]

Toporišič, J. (1976/2000). Slovenska slovnica. Maribor: Obzorja. [in Slovene]

Trubetzkoy (1939/1969). Principles of Phonology. Trans. C. Baltaxe. Berkeley: University of California Press.

Vaissiere, J. (1983). Language-independent prosodic features. In A. Cutler \& D. R. Ladd (Eds.) (1983). Prosody: Models and Measurements (pp. 53-66). Berlin: Springer-Verlag. 
